\title{
Syphilis of the spine
}

\author{
MATTI HANNUKSELA AND ERKKI O. KARAHARJU \\ From the Departments of Dermatovenereology and Orthopaedics and Traumatology, University Central Hospital, \\ Helsinki, Finland
}

The manifestations of late syphilis are rarely seen nowadays. In the Oslo study, benign tertiary syphilis occurred in 15.8 per cent. of 1,147 patients with untreated syphilis. The commonest sites of 'benign' tertiary syphilis were the skin, the mucous membranes, and the bones $(70.0,10.3$, and 9.6 per cent. of all cases, respectively) (Gjestland, 1955). Thus, syphilis affecting the bones can be expected in about 1.5 per cent. of patients with untreated syphilis. Nielsen (1950) found manifestations of tertiary syphilis in $1 \cdot 1$ per cent. of his cases of partially treated syphilis.

Gumma formation in the bone tissue leads to destruction of the bone. The tibia, skull, and sternum are affected more often than other bones, and gumma of the spine is extremely rare. The precise frequency of spinal manifestations has not been analysed, but some case reports of this complication have been published in the last few years (Johns, 1970).

Syphilis can simulate other granulomatous diseases, e.g. tuberculosis. It is very difficult to establish the correct diagnosis from radiographs and histological examination alone. Positive serological tests for syphilis (STS) and, especially, positive treponemal tests are highly suggestive of syphilis in questionable cases.

The frequency of early syphilis has slowly increased in most European countries in the last 10 years. Obviously, some of these patients are treated inadequately or not at all, and will later suffer from syphilitic complications. This paper presents the case history of a 38-year-old man with probable syphilis of the spine.

\section{Case report}

A painter aged 38 was first seen in March, 1967, at the Department of Orthopaedics and Traumatology. He had no history of serious disease. The first spinal symptoms occurred in spring 1966. After strenuous work, he began to suffer from aching and pain in the lumbosacral area. Quickly worsening radicular pain appeared in the right leg in August, 1966, and within 2 months the patient was

Reçeived for publication May 1, 1972 unable to work. He visited a district physician whose diagnosis was sciatica.

When first seen at the Department of Orthopaedics and Traumatology, the patient complained of aching and numbness in the legs. The symptoms were aggravated by movement; even walking some 500 metres was enough to make the pain excruciating.

\section{Examination}

There was partial sensory loss in the feet and the distal parts of the legs. Ankle and knee jerks were absent, but there was no weakness. Lasègue's sign was negative bilaterally.

$\mathrm{X}$-ray examination revealed narrowing of the intervertebral space between $\mathrm{L} 4$ and $\mathrm{L} 5$ and a spondylolisthesis of $11 \mathrm{~mm}$. affecting the fourth lumbar vertebra (Fig. 1).

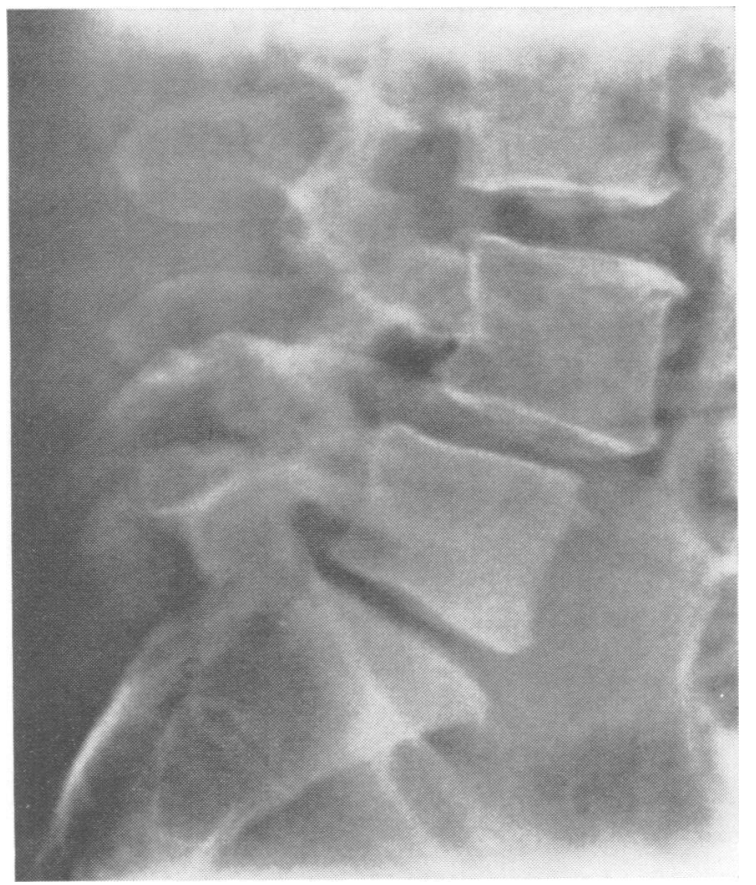

FIG. 1 March, 1967. Spondylolisthesis of $11 \mathrm{~mm}$. involving $L 4$ with narrowing of intervertebral space 
The erythrocyte sedimentation rate (ESR) was $9 \mathrm{~mm}$./ 1st hr, haemoglobin $16.4 \mathrm{~g} . / 100 \mathrm{ml}$., and white blood cell count 8,100 per cu. mm. Routine urine tests revealed nothing abnormal.

The Kahn and VDRL slide tests were positive. The patient denied that he had ever had venereal disease and no signs of past or recent syphilis were found. However, both the TPI test and the FTA-ABS test were positive in the serum.

Neurological examination showed changes compatible with spondylolisthesis, but none suggestive of neurosyphilis. The cell count in the cerebrospinal fluid was normal, but the protein was slightly increased $(52 \mathrm{mg} . / 100 \mathrm{ml}$.). The Kahn, VDRL slide, TPI, and FTA-ABS tests were negative. Spondylolisthesis was considered to be the cause of the patient's symptoms and antisyphilitic treatment was not given.

\section{Progress}

In January, 1969, the patient was admitted to hospital again for increasing aching and pain in the lumbar region and lower limbs. He was unable to walk more than 200 metres at a stretch.

The results of serological tests for syphilis in the serum and the cerebrospinal fluid were the same as 2 years previously. $X$-rays of the lumbar spine revealed marked narrowing of the intervertebral space between L4 and L5 as well as distinct spondylitic changes (Fig. 2). Total

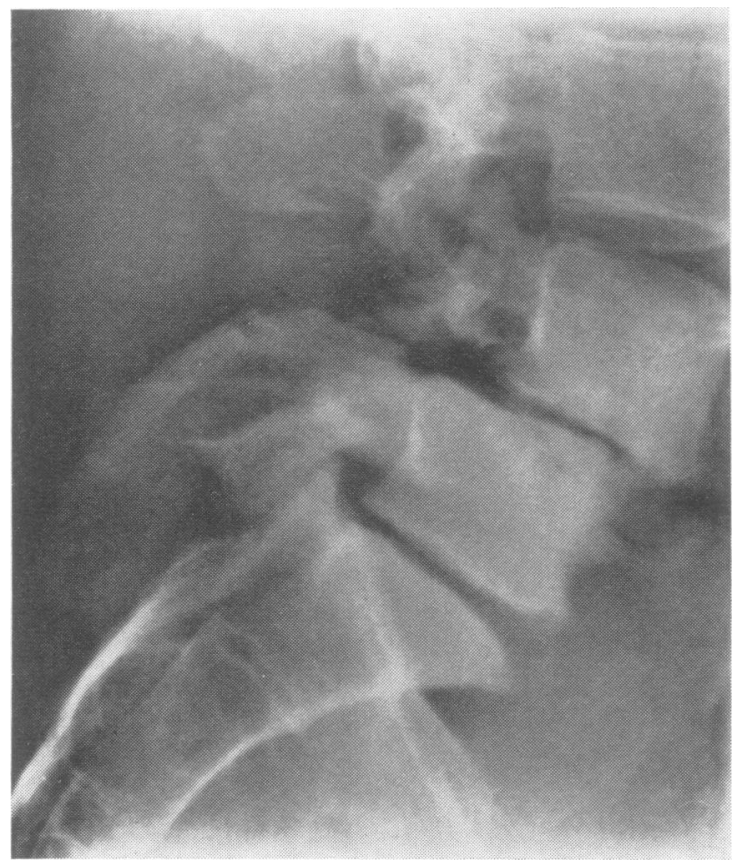

FIG. 2 February, 1969. Marked narrowing of L4 to 5 intervertebral space and spondylitic changes in adjoining vertebrae block at the level of L4 to 5 was observed at myelography. After consulting venereologists, the patient received 600,000 units procaine penicillin daily for 15 days.

A decompressing laminectomy of the fourth lumbar vertebra was performed one month after the course of penicillin. During the operation, fibrous tissue was found in the ventral part of the neural canal. Histologically this tissue consisted of granulomatous inflammation compatible with gummatous tissue reaction, but indistinguishable from tuberculosis. In the Mantoux test, $0 \cdot 1$ tuberculin unit of purified protein derivative gave a negative result.

\section{Result}

At a follow-up examination in June, 1971, the patient's subjective condition was unchanged. He was still unable to work as a painter or do any other manual work. Bony consolidation between the fourth and fifth lumbar vertebrae had taken place (Fig. 3) as an end-result of the healed inflammatory process.

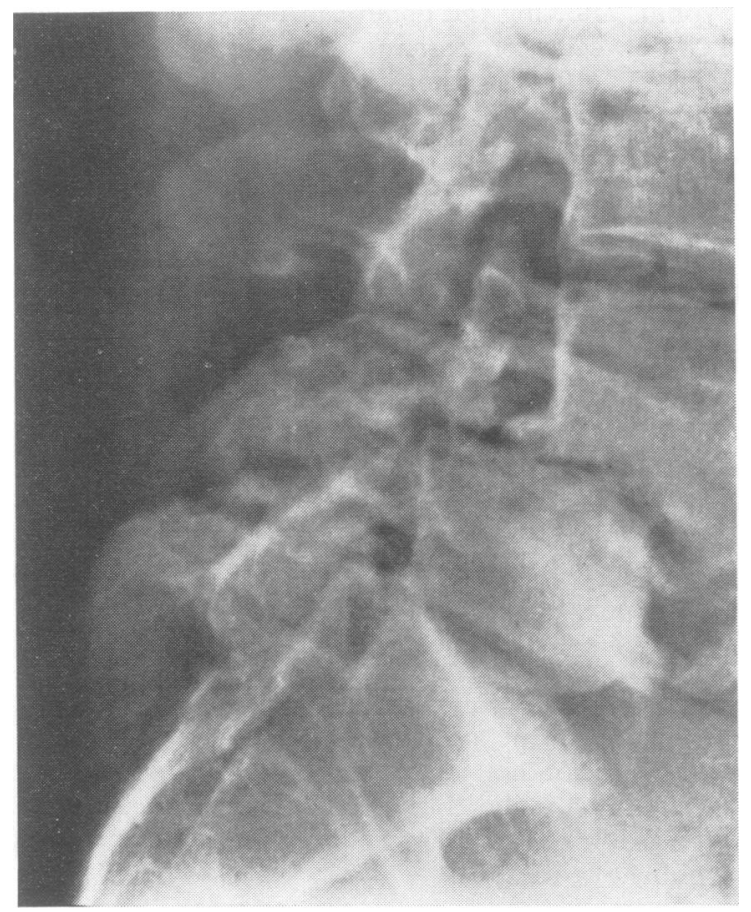

FIG. 3 Fuly, 1971. Bony consolidation between L4 and 5 as an end-result of healed inflammatory process

\section{Discussion}

Spondylitis due to pyogenic bacteria and tuberculosis still exists, but it is rate. Tertiary syphilis is even more rare as a cause of infective destruction of the vertebrae. We do not know the frequency of 
gummatous spondylitis in untreated syphilis because this form of syphilitic complication has been documented only in occasional case reports.

In the case presented here the changes in the vertebral column were considered primarily as signs of spondylolisthesis, and the patient was not given treatment for syphilis, but when the destructive changes were seen radiologically the correct diagnosis was established.

Tuberculous spondylitis should also always be kept in mind in cases of destructive spondylitis. In the present case, there was no history of tuberculosis, the ESR was repeatedly below $15 \mathrm{~mm}$. $/ \mathrm{hr}$, and the tuberculin test with 0.1 tuberculin unit of purified protein derivative was negative. The histological and $x$-ray findings were compatible with both tuberculosis and gumma. The positive standard and treponemal tests for syphilis as well as the apparent healing after antisyphilitic treatment support the diagnosis of syphilis.

During the second world war, the incidence of early syphilis rose to 125 new cases per 100,000 population per year in Finland. In the 1950s and early 1960 s, it nearly disappeared, but recently the annual number of new cases of syphilis has started to increase (Lassus, 1971). Because some cases of early syphilis may remain untreated, or may be inadequately treated by therapy prescribed for some other infection, we must still bear in mind the possibility of the future occurrence of rare manifestations of late syphilis.

\section{Summary}

A very rare manifestation of untreated late syphilis, gummatous spondylitis, was observed in a 38-yearold man. The condition was first considered to be a true spondylolisthesis, but spondylitic changes later became obvious in the fourth and fifth lumbar vertebrae. The Kahn, VDRL slide, FTA-ABS, and TPI tests were positive in the serum but negative in the cerebrospinal fluid. A tuberculin test, using $0 \cdot 1 \mathrm{TU}$ of PPD was negative.

The patient was treated with 600,000 i.u. procaine penicillin daily for 15 days, and 1 month later, a decompressing laminectomy was performed. During the operation, fibrous masses were found in the ventral part of the neural canal, which were histologically compatible with a gummatous tissue reaction, but indistinguishable from the lesions of tuberculosis. The inflammatory process in the spine eventually healed.

This patient probably had tertiary syphilis of the spine. Although gummatous lesions in the vertebral column must be very rare indeed, they should be kept in mind so as to avoid a wrong diagnosis and incorrect treatment.

\section{References}

Gjestland, T. (1955) Acta derm.-venereol. (Stockh.), 35, Suppl. 34

Johns, D. (1970) f. Bone ft Surg., 52-B, 724

LAssus, A. (1971) Suom. Laak.-L., 26, 1640

Nielsen, J. P. (1950) Acta derm.-venereol. (Stockh.), 30, 507

\section{Syphilis rachidienne}

\section{SOMMAIRE}

Chez un homme de 38 ans on a observé une spondylite gommeuse, très rare manifestation de la syphilis tardive non traitée. Ce cas fut d'abord considéré comme une spondylolisthèse vraie mais des altérations spondyliques devinrent, ultérieurement, évidentes pour la quatrième et cinquième lombaire. Le Kahn, le VDRL sur lame, le FTA-ABS et le test d'immobilisation étaient positifs dans le sérum mais négatifs dans le LCR. Une épreuve à la tuberculine, utilisant 0,1 unité de PPD, fut négative.

Le malade fut traité par $600.000 \mathrm{u}$. de pénicillineprocaine chaque jour pendant 15 jours et, un mois après, une laminectomie de décompression fut pratiquée. Pendant l'opération, on trouva des masses fibreuses sur la partie ventrale du canal neural qui, histologiquement, pouvait correspondre à une réaction gommeuse mais n'était pas différenciable de lésions du tuberculose. En fin de compte, le processus inflammatoire du rachis guérit.

Ce malade avait vraisemblablement une syphilis tertiaire du rachis. Quoique les lésions gommeuses de la colonne vertébrale doivent être à la vérité très rares, il ne faut pas les oublier pour éviter un faux diagnostic et un traitement incorrect. 